$\begin{array}{lcc} & \end{array}$

\title{
Toward a bridge theory of modernity: Seeing self and society as processes
}

\section{Richard Morehouse}

Emeritus Professor of Psychology, Viterbo University

\begin{abstract}
The examination and exploration for the nature and meanings of Modernity have been recently presented in philosophy, sociology and psychology books and journal articles. This article presents some of the important ideas in these disciplines and provides a perspective that integrates three disciplines (Philosophy, Sociology, and Psychology) and five authors' views on Modernity (Charles Taylor, Jaan Valsiner, Anthony Giddens, Herbert Hermans, and Hartman Rosa). The paper first presents an overview of these authors. It goes on to illustrate several common themes of their work: 1) the role of narrative and a semiotic perspective as tools for understanding modernity, 2) a developmental orientation and exploration of how self and society might be seen as developmental processes, and 3) a beginning of a reorienting of philosophy, sociology and psychology as interconnected disciplines. The goal of presenting the views of these authors is to gain a perspective on why it is valuable to understand the historical period we live in (modernity), the roles played by narrative and semiotics and the developmental nature of humans and their *Correspondence to Author: Richard Morehouse Emeritus Professor of Psychology, Viterbo University culture, and how listening to the melody and tone of modernity aids in understanding modernity.

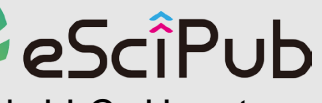

eSciPub LLC, Houston, TX USA. Website: https://escipub.com/
\end{abstract}

Keywords: Modernity, Moral Topography, Semiotics, Narrative, Taylor, Valsiner, Giddens, Hermans, Rosa 


\section{Introduction}

The major theorists reviewed here (Taylor, Giddens, Valsiner, Hermans, and Rosa) all have articulated a view of society and the self as processes. However, perhaps the most helpful perspective on the connection between self and society as a process is best articulated in the Sources of the self: the making of the modern identity (Taylor, 1998). Charles Taylor (1989) creates a historical narrative of the intertwined nature of self and society. An essential part of that narrative is understanding the moral topography ${ }^{1}$.

The multiple connections are a part of what is suppressed from view by those contemporary modes of thought which have no place for the good. They are quite unaware of the way in which our modern sense of self is bound up with independence and depends on what one can call a 'moral topography'. They tend to think that we have selves in the way we have hearts and livers, as an interpretation-free given. And of course, they have no sense at all of the inverse relationship (106).

If we can gain an understanding of moral topography, perhaps we can better understand the self and society as processes. Moral topography is tied up with a sense of agency. Moral topography is being able to occupy the moral space wherein we have a perspective of ourselves as agents within a moral landscape. Taylor presents two views of the person. From one perspective, an agent is any being who acts; that is, who has goals and end that she tries to gain them (Taylor, 1988, 103). Thus, animals have agency.

However, there is another view of agency that understands agents as distinct beings: this is the view of agency that is important for us to understand within a social perspective. Agents are beings for whom things matter and whom others value as well they are persons who others recognize as important, and who are valued by others (Taylor, 1998). Or as Erik Erikson put it “

In finding it the young adult gains an assured sense of inner continuity and social sameness which will bridge what he was as a child and what he is about to become and will reconcile his conception of himself and his community's recognition of him (Erikson, 1959, 111).

In Charles Taylor's words,

The essence of evaluation no longer consists in assessing in the light of fixed goals, but also and even more in the sensitivity to certain standards, those involving the particular human goals. The sense of the self is a sense of where one stands in relation to the standards, and properly personal choice is one informed by those standards. The center of gravity thus shifts in our interpretation of personal capacities. The center is no longer the power to plan, but rather the openness to certain matters of significance. This is now what is essential to personal agency (Taylor, 1985, 105).

And this center of gravity is Taylor's "the good," a core spatial metaphor explained in his construction of moral topography. The coordinates of that moral landscape formed by our moral sources, that is, those characteristics of life that we strive towards (Christopher, 2007, 172). The moral sources include justice, responsibility, dignity, and seeking a fulfilling life. And finding the place where one stands is an activity, a process that is central to a changing and evolving self, and in a changing and evolving society. While the quote from Taylor does not, in itself, provide an explanation of modernity and the self as processes, this theme will be developed as this article unfolds. I will try to show that society and the self are better seen

\footnotetext{
${ }^{1}$ Topography is arrangement of the natural and artificial features of an area, thus moral topography is the arrangement of the features of the landscape of ethics and
}

morality. It provides a picture of the space, the environment in which we live. 
as processes; they, however, are implicitly assumed that to be more or less static.

To provide an understanding of late modernity, the authors discussed in the cur-rent study have focused on some common themes and concepts. These include but are not limited to separation and confluence of time/space, the role of life-style (individuality /conformity), the influence of localization/globalization, the causes of emancipation/suppression, meaningmaking, and the nature of reflexive self-identity. There are implicit and sometimes explicit refrains running through these discourses as may be seen in the below list of themes and concepts in the discussion of modernity, i.e., the self. The self is also characterized as personality, identity, or what it means to be human. The characterization of modernity, provided here, attempts an understanding and articulation of the formative logic operating in the background behind modernity's various manifestations. Anthony Giddens defines late or high modernity as a tool for understanding the times in which we live. "In high modernity, the influence of distant happenings on proximate events, and intimacies of the self be-comes more and more commonplace" (1991, p. 4). Giddens's characterization of high modernity highlights two concepts 1) the shrinking of distance and the truncating of time as influences on present events, and 2) the creation of an internal referential system shaped by the previously mentioned qualities. Hartmut Rosa's, Resonance: a sociology of our relationship to the world (2019), presentation of modernity, while drawing on and criticizing Max Weber, Émile Durkheim, Karl Marx, Theodor Adorno, Max Horkheimer, Herbert Marcuse, and Erich Fromm among many others, offers a somewhat different perspective on modernity while also focusing on the temporal elements of time and distance. This social formation of modernity is defined structurally by the fact that it is capable only of dynamic stabilization2, while its cultural program is aimed at systematically increasing the share of the world of both individuals and cultures (Rosa, 2019, p. 308).

With this tentative and evolving definition of modernity, I will now focus on the five theorists whose writing is the main focus of this paper come from three overlapping disciplines (Philosophy, sociology, and psychology). They are influenced by the vocabulary, history, and perspective of the discipline in which they write, nonetheless, their personal intellectual histories and traditions have created a useful and integrated mosaic. The articulation of the human condition is to a considerable degree viewed as developing over time. This developmental perspective provides the backdrop within which they explore modernity.

The purpose of this paper is to make the images within this mosaic more coherent by focusing on dominant themes as well as some of the subtle undercurrent of modernity. We, humans, understand ourselves through language and lived experiences within a culture. Examining the meaning of modernity as a process is the goal of this article. Herein, we set out to struggle with several questions: How does looking at historical periods help us understand modernity? What roles do narrative and semiotics play in human and cultural development and modernity? How does the contextualization of a relational world influence its melody and tone?

To create that more coherent picture the work of Charles Taylor will be used as a tool for unifying these varied outlooks. But first I begin with on orientation for studying modernity as a process.

\section{An orientation for studying modernity as a process.}

Let me begin by putting forward two approaches for understanding. Approach one, using Rosenberg's The not so common sense, (2002) as a guide, offers a case for understanding social and political perception and awareness within a communication matrix. This work delineates three types of thinking: sequential thinking, linear thinking, and systematic thinking. These ways of thinking are based on an 
underlying structure for the disparate understanding and judgments that a given individual constructs (Rosenberg, 2002, 1). Rosenberg uses what he calls pragmatic structuralism for his theoretical tool. The second approach draws on the work of Jerome Bruner's and Michael Polanyi's hermeneutic cycle as an explanatory tool.

\subsection{Understanding social and political} perception and awareness within a communication matrix.

Modernity as a process is a difficult concept to understand, even for academics and the wellinformed reader. The focus here is on systematic thinking because the goal is to present a framework for thinking specifically about modernity, not to discuss Rosenberg's theses. Systematic thinking "emerges with the objectification of the concrete and anchored relationships previously established. "Structural thinking is an essentially interpretive activity. It involves making sense of events by juxtaposing the relationships among interactions and propositions. In this manner, a number of observed actions and assertions are of facts or preferences may be considered simultaneously" (135). Systematic thinking generates a certain self-consciousness of its activity. Looking intentionally at understanding self and society provides an example of how this type of thinking works; To understand self changes our understanding of society and the understanding of society changes our understanding of the self.

Given the manner of their construction, systematic principles are twice removed from the specific of observed concrete action. Whether they link two classes of interaction or a class and a system, they consist of a relationship between two relationships. They are doubly abstract and therefore tend to be quite broadly applied $(2002,146)$.

This double abstraction is both an impediment to understanding and a clue for understanding. This paradox will be better understood when we look a Jerome Bruner's hermeneutic thinking approach and then Michael Polanyi's Personal Knowing.

2.2 Narrative, the hermeneutic cycle and tacit and explicit knowing as a tool for understanding

A narrative understanding of the world and human acts is central to understanding modernity, so we begin with presenting the elements of a narrative. Narrative requires, according to Bruner (1990), the following grammatical constituents, (1) a means for emphasizing human action directed toward agent-controlled goals, (2) the maintenance of a sequential ordering in a linearized standard way, (3) a sensitivity to what is canonical and what violates the canonical in human activity, and (4) a voice (77). With that initial definition of narrative, the hermeneutic cycle will be presented. The hermeneutic cycle, as popularized by Dilthey and as used by Jerome Bruner in Acts of meaning (1990) is a tool for interpreting behavior, texts, and other meaningful material such as art and architecture. But what exactly is the hermeneutic cycle? The hermeneutic cycle is a way of understanding the whole by looking at the individual parts, that is, the details, and understanding the details by examining the whole. Neither the big picture (the whole) nor the narrow focus (the individual parts) can be understood without considering the other. Understanding comes from the cycle of whole to part to whole again, in an on-going cycle. This cycle, rather than making interpretation impossible, makes the activity or text meaningful within the context of its culture, history, and/or literary context.

Understanding the hermeneutic cycle is step one for providing an orientation to modernity as a process. Step two is getting a handle on Michael Polanyi's Personal Knowledge: toward a post-critical philosophy (1958a). One of Polanyi's arguments in this work is that much of what we understand we understand tacitly, that is we understand in the act of doing. That inarticulate or tacit knowledge that we use as we go about our daily lives works well until a unique 
problem arises or solutions don't work together or are in conflict. But before looking at tacit and explicit knowledge, a look at subsidiary and focal perspectives is in order.

In The study of man (1958b), Polanyi writes, "Living beings and processes of life are known to us by personal acts of comprehension" (57). This idea is expanded in Personal Knowledge. In his last chapter, Polanyi writes that the value of his book is to re-equip us with the faculties to see a picture of knowing, that is, to a stance toward knowing based on interpreting the world. The goal is to restore knowing to its fairly obvious nature.

For once men have been made to realize the crippling manipulation imposed by objectivists framework- once the veil of ambiguity covering up these manipulations has been definitively dissolved - I think many fresh minds will turn to the task of reinterpreting the world as it is, and as they once more will see it to be (1958a, 381).

This restoration begins with understanding the relationship between subsidiary and focal perspective-taking. This perspective-taking is closely related to the whole/part relationship earlier discussed the topic of hermeneutics. To understand something, we need to look away from the individual part and focus on the whole, but that perspective changes as we examine the details by focusing on the parts. This process goes back and forth between focal attention and subsidiary attention as we create an integrated understanding of that thing. He argues that one understands something by only understanding it as a whole but being subsidiarity aware of its particulars and by a meaningful study these particulars lead us to understand the whole. To understand persons, things, and systems we must indwell, we must commit ourselves, that is, become involved with what we seek to know.
Critical understanding is the next step. It begins with a tacit understanding and articulate understanding. "Only explicitly formulated knowledge can be best derived true specifiable premises according to clear rules of inference. It is the most important function of critical thought to test such processes of reference, by rehearsing their claim and reasoning in search of some weak link" (1958b, 17)2. By evaluating these claims and the reasoning that supports them we arrive at important, but tentative, knowledge. That process varies to some degree but the rules of conducting research and verifying results. But, according to Polanyi, it is connoisseurship that is its backbone. Connoisseurship is communicated only by example, not by precept. To be a connoisseur of knowledge, as with any other skill, you must go through a long course of experience under the guidance of a master.

\section{Overview of several theories of modernity and their implication}

There is a paradox that dominates any attempt to study modernity. That paradox may be stated as follows: We already understand the world because we are functioning within it, but at the same time we are ignorant of many of the things that shape our actions in the world. I have already hinted at some for the ways that have contributed to understanding how living within while having a limited understanding of modernity can be addressed, namely, the role of systematic thinking, the value of the hermeneutic cycle, and the application of the tools of subsidiary awareness and focal awareness and tacit and articulate knowing. While these ways of knowing are not usually stated specifically during the presentation of the theorist of modernity discussed in this section of the paper, it is hoped that the reader will see how these thinking processes are implicitly used.

\footnotetext{
${ }^{2}$ Notice the subtle similarity of the critical thinking in the checking process with Bruner's understanding of the role of the non-canonical in narrative.
} 


\subsection{Charles Taylor and the making of the modern age}

Charles Taylor's narrative, using what you know, however tangentially, to help you scale the peeks and plum the valleys of the history of the self and modernity. The title alone, Sources of the self: the making of modern identity (1989) says much about what we might find between the covers of the book. Perhaps most obvious is that the self is modern, and it is made: its making is a process to be understood, and a process that continues today. We are selves in the making. Taylor's method is to provide a history of society and the self, I argue, as both process and entities.

Charles Taylor (1989) claims that an appreciation of the relationship between self and society is better understood with the help of a conceptual tool he calls moral topography. What we're constantly losing sight of here, Taylor argues, is that being a self is inseparable from the existing in a space of moral issues, to do with identity, and how one might be. It is being able to find one's standpoint in this space, being able to occupy, to be a person with a perspective of it.

Now I will contextualize these questions within a larger framework, that is, modernity as a process and as an entity. Key to understanding modernity as a process is a linguistic and conceptual consensus that makes swift and widespread communication possible. As a small example of how modernity may be seen as a process, Charles Taylor (1989) presents one such change, that is, the disenchantment of the world. The world was enchanted and disenchanted through the use of language. This will be discussed in greater detail later, but for now, a quote from Jerome Bruner's essay on "The control of human behavior" (1962) will provide one clue as to how language of demand and concept development are a part of the process of modernity.

Language is the human gift that is the chief guarantor of joint action, it comes into its first use at a time when joint action is the only means whereby the young human organism can survive. Consequently, early language is essentially demand language, a two-way demand language. But language learning is also concept learning, and the price one pays for the gift of language is that one also learns to operate in terms of the concepts that are codified in the language- all concepts of relationships, of modification, and cause and effect. ... It is this cognitively predispositioning property of language that has been called its Weltanschauung. (1992, 137-8).

That quote by Bruner with its reference to the formative role of concepts as a codifier of relationships and its role in creating worldviews, such as "the disenchantment of the world," gives support to Taylor's argument that intellectuals have played a significant role in demythologizing our world of myth, but, on a hopeful note, also suggest that intellectuals may also contribute to the creation of positive cultural myths (1962, 139).

The understanding of modernity and the self as processes begin by looking at the individual, the self, as always within a language community: it is this situatedness that allows the individual to affect the community and the community to affect the self. It is appropriate, therefore, to see both the self and society as a process, as a society affects the individual and the individual (the self or agent) affects the society as they are in a constant state of oscillation between continuity and change. Both the individual and the community have been around to millennia, however, our understanding of these entities has evolved. A second idea, a language community, also implies processes. It is semiotic tools that allow us to experience the interplay between self and society.

"Spanning multiple decades, Charles Taylor's writings have provided interpretations of human life and action, as well as modernity itself that resonates with readers (whether in agreement or disagreement) while simultaneously articulating something that went beyond our existing 
knowledge" (Bohmann, Keding, \& Rosa, 2018, p. 725). Some have seen Taylor not just as a bridge between the social or human sciences and philosophy, but rather as a philosophical anthropologist (Mattingly, C.,Lutkehaus, N.C. and Throop, C.J., 2008) ${ }^{3}$.

In Sources of the self, Taylor traces the origins of self or identity as a way of understanding the nature of the modern age.

I want to explore various facets of what I called modern identity. To give a good first approximation of what this means would be to say that it involves tracing the various strands of the modern notion of what it is to be a human agent, a person, or a self. ( $p$.

1)

This opening makes a point that is explored through this essay, that is, modernity and self are intrinsically intertwined. This point may easily be assumed on one hand, or alternately denied, or undervalued. However, Taylor makes the case that this intertwining of person and morality, namely the self is not always been understood as we now understand it to be, that is, an autonomous moral individual. He argues that this concept, this understanding has a developmental history. Human agency, a person, or a self are essential concepts in the development and understanding of modernity, that is, the evaluation of human desire is the history of the development of agency. "But what is distinctly human is the power to evaluate our desires, to regard some as desirable and others as undesirable. ...this capacity to evaluate desires is bound up with our power of selfevaluation" (1985a, p. 16). The concept of agency evolved together within the context of personal narratives. These concepts grew in complexity as the idea of a person as an agent evolved over millennia. To be an agent is to be engaged as a moral being. Beginning in childhood we learn language through our movement in space, by understanding up and down, near and far, empty and full. By understanding our bodies in the world, we come to understand the concept of movement and direction, the concept of containment as well as interiority, and the concept of balance and standing upright among many others ${ }^{5}$ (Bohmann, Keding, \& Rosa, 2018)

In what ways are selfhood and morality intertwined? Before answering that question, Taylor states that he is reluctant to define a person but poses a tentative definition - a person is an agent, that is, a person is capable, to some degree, of choice. The idea of a person carries within it a moral and legal status. That legal and moral status is exemplified in the ability to make life plans; it is to take responsibility for the exercise of one's plans. "A person is a being who has a sense of self, has a notion of the future and the past, and can hold values, make choices; In sort can adapt life plans" (Taylor, 1985a, p. 97). As we can make choices, we can ask questions regarding what makes life worth living.

These two concepts grew in complexity and connectivity as the idea of a person as an agent evolved together within the context of personal narratives. To be an agent is to be a narrative creator who engages others within a storied and commonly constructed world. Understanding our stories, our lived experiences creates a demand for respect and that some sense of respect is a human universal. Perhaps the most urgent and powerful cluster of demands that we recognize as moral or ethical, that is, concerns respect for life, integrity, and well-being, even flourishing for ourselves and others.

\footnotetext{
3 In support of that assertion, Taylor in some of his early works has addressed the connection between philosophy and social sciences, human agency, human beings as self-interpreting animals, an what is genetic psychology? are discussed in Human agency and language (1985a). In Philosophy of human nature (1985b), he writes about interpreting the science of man, and social theories in the practice of social theory. In Philosophical arguments, (1995) he discusses Heidegger, language
}

in ecology, and the politics of recognition, among other topics. All these matters find their way into the Sources of the self: the making of the modern age (1989) and will provide an important bridge between the Social Sciences and Philosophy within the context of modernity that will be discussed in the final part of the paper. 
Respect, according to Taylor, is central to moral thinking and presupposes agency.

But pursuing this investigation soon shows you can't get very clear about this without some further understanding of how our pictures of the good have evolved. Selfhood and the good, or in another way, selfhood and morality, turns out to be intrinsically intertwined themes (p. 3).

An understanding of morality needs to address the question "what is the good life?". The "good life" is the experiences of having lived a full and rich life. The good life is to some degree made of choices. We choose our future by making commitments. And our future can only be understood in relation to our past choices and our present understandings. Choice arises within options between and among a variety of commitments. At the core of agency is a commitment; Commitment is simply an obligation to do something in the future (Moya, 1990. p. 61).

Commitments are linguistic entities; it is through the language of commitment that selves are formed. To be an agent is to speak and act. Taylor states that I define who I am by "where I speak from, in the family tree, in social space, in my intimate relationships to the ones I love" (1989, p. 35).

There is no way we can be introduced into personhood except by being initiated into language. We first learned our languages of moral and spiritual discernment by being brought into an on-going conversation by those who bring us up. The meaning that the keywords first become for me are the meanings that they have for us, that is, for me and my conversational partners together (1989, p. 35).

This semiotics turn is extended in $A$ secular age (2007), wherein Taylor outlines what he calls the buffered self. The buffered self is partly a matter of living in a disenchanted world, that is, in a world that has closed the porous boundaries between the inside and the outside (p. 300. This buffer self comes about by replacing a cosmos of spirits with forces of mechanical potency, by favoring self-regard instead of endowed gifts; By replacing custom and tradition with novelty and pleasure. In that work, he points out the positive side of the buffered self, that is, a self that is disenchant-ed is a self that has a sense of invulnerability; a self who is living in an Anthropocene and disenchanted world. The negative side of disenchantment is the weakening or disappearance of religion and tradition as anchors or retreats. Enchantment and disenchantment are both embodied in a sense of what it means to be moral.

This moral perspective is also developed in his more accessible work, the authentic self (1991) in which he writes about the malaise of modernity. Malaise is a nonspecific feeling of discomfort. Taylor identifies three malaises as dissatisfactions or discontents in late modernity (1) the loss of meaning, (2) the ellipse ends ${ }^{4}$, and (3) the loss of political freedom.

As a part of this description of meaning is the fading of moral horizons, Taylor argues that in late modernity we have lost many rituals and norms that have a value-based significance and that when we discredit values (1) we disenchant the world which leads to a life without aspiration. This malaise leads to what he calls the ellipse of ends (2), meaning that we may not seek ends and only focus on the means, that is, the instruments of attaining what we have left undefined. When our moral horizons have faded and we no longer have a sense of what ought to be, political life is lost. Instead of political life (3), we have a soft despotic governance framework which includes voting in some forms of democracy, what it is a government-organized around a protective power without a political culture that integrates government and voluntary associations. Democracy needs, to be vibrant

\footnotetext{
${ }^{4}$ This is what Hans Vaihinger (2009) calls "Preponderance of the Means over the Ends
} 
and alive, a culture that encourages debate in a critique of what is as well as what might be.

But to engage effectively in this manyfaceted debate, one has to see what is great in the culture of modernity, as well as what is shallow or dangerous. As Pascal said about human beings, modernity is characterized by grandeur as well as by misère. Only a view that embraces both can give us the undistorted insight into our era that we need to rise to its greatest challenge (Taylor, 1991, p. 120 - 121).

If we are to address the discontent of our time, we need to examine the origins of the self and the meaning of a good life within a context which recognizes the importance of the greatness and misery of modernity as well as its more subtle hills and valleys.

\subsection{Jaan Valsiner's Sociogenetic approach to} personality as a tool for thinking about modernity

In Beyond the mind: cultural dynamics of the psyche (Marsico, 2018) explore the changing nature of the self or our entity as referred to below,

We do not 'have' entities but are constantly in the process of creating them-through sign hierarchies oriented to our own selves- and treating the constructions as if they were permanent" (p.51).

Perhaps one of the defining characteristics of modernity is the recognition that we are constantly in the process of creating semiotically defined selves. (1) As a semiotic approach to modernity appears to be one of the ways that all of the theorists of modernity use, in varying degrees, and that self or personality is central in the discussion of modernity across theorists and disciplines, a semiotic approach to personality is of considerable value. Valsiner's approach is to use semiotics as a unifying theme for understanding the self. Valsiner ties three ideas together in the course of three books (Valsiner, 1998; Valsiner \& van der Veer, 2000; Marsico,
2018). Prominent among these ideas are identity or the self is not a thing to be possessed but a process that is developing and changing. The second element is this effort to understand the patchwork patterns of modernity and the self is (2) the evolutionary, or historic nature of modernity. One of the challenges of modernity is that there is no consensus as to when it began. While Valsiner's placement of the self solidly within the history of sociology and psychology, does not definitively set a beginning point for modernity or late modernity, this evolutional/ historical approach does, I think, provide an anchor for the exploration of the self and modernity. (3) Humans are meaning-makers who create purpose and value while differentiating themselves from their environment and to some extent creating their future.

The constant re-creation of the self involves goal - oriented action in the present moment while incorporating past and future actions and selves. Signs are a catalyst for the creation of human acting, feeling, and thinking. The three elements of goal-oriented action, resistance to action, and reflection upon action enable persons to integrate higher psychological functions with their lower counterparts through future-oriented semiosis by making signs, creating sign configurations, and setting up catalytic conditions for the future person to re-create themselves. (Marsico, 2018).

It is through the construction, used, and modification of signs that the human personality becomes a self-organizing system that constantly reconstructs itself. "The social environment is to be viewed as making it possible for a personality system to rearrange itself in many unique forms, not necessarily along the lines of social expectations of any particular setting" (Valsiner, 1998, p. 386-7). The production of meaning is an important element in semiotics as it helps to explain the openended nature of personality. The open-ended and future-oriented orientation is made possible by the use of signs. This symbiotic move 
provides a lens for looking in two directions simultaneously (person $<>^{5}$ culture).

The human construction of signs establishes a relationship between a persons' identity and their culture. The person is the source of agency as a sign maker. "[S]igns are subjectively constructed, interpersonally consolidated, and stored in both intra - and interpsychological domains" (Valsiner, 2001, p. 87). Semiotics provides, to use a biology metaphor, two-way permeability between an individual's ability to shape society in the society's ability to shape the individual personality. Valsiner uses a slightly different metaphor when examining the nature of culture in his personality; He uses the regulatory genes of modern genetics of protein synthesis as his metaphor. From the perspective of specific systemic relations between regulatory genetics, "agents make it possible (or impossible) for a particular protein structure to be built" (390). To apply this metaphor, some human agents enable (or prohibit) further construction of new semiotics structures, that is, within the semiotic theory, new signs can be made, new meanings can be given to all signs. The theory allows the flexibility of operating concurrently (as well as sequentially) at a variety of levels of abstraction. New ways of reflecting upon any situation of human psychological processes make for an infinity of possibilities.

Valsiner's sociogenic approach to personality comes together within the context of cultural psychology which he understands is being at the intersection of social and developmental psychology and anthropology. Theory and methods are integrated into this intersection of disciplines. Developing together, each influence each other, rather than culture as a phenomenon in which human development emerges, anew light is cast on individuals and the culture.

As culture and psychology are developmentally based aspects of Valsiner's approach, a quick word about the development of culture with a with help from Jerome Bruner's Actual minds, possible world, (1985) and Acts of meaning (1990) makes clear one aspect of that development. Bruner argues that man's mental powers are developed through culture, and culture is what makes it possible to construct human psychology; Psychology can't be constructed based on the individual alone. Therefore, psychology must be organized around those meaning-making and meaningusing processes that create and connect us to culture. It is within the culture that meaning is made public and shared. Thus, these meaningmaking and meaning-using processes are what Valsiner calls sociogenetic processes.

For there to be a two-way influence between the self and the environment two distinct entities are needed. "The person and the environment are both separate and united; separation makes it possible to study their actual relationship as a process" (Valsiner, 1998, p. 21). These two entities are, from Valsiner's understanding, placed in relationship to each other: the person increases his or her autonomy, while the culture sets limits within a bounded indeterminacy. It is this manner that the person influences culture and the culture influences the person.

The creation of the future is another closely related and important element in Valsiner's sociogenic personality theory. A person living in late modernity actively constructs his/her personality; this person helps his /her development by setting goals, attempting to accomplish them, and abandoning these goals as appropriate (Valsiner, 1998, p. 28). Operating with a telegenic ${ }^{4}$ and feed - forward agenda, the construction of identity is oriented towards a process of becoming; while maintaining relative temporal stability, in this manner a person creates a personality. Each person's individual development is uniquely constructed within an irreversible lifetime. This uniqueness is possible in principle when there exists a multitude of

\footnotetext{
${ }^{5}$ Valsiner uses $(<>)$ the representation to illustrate a two-way relationships.
} 
possible developmental trajectories (p. 29). It is a forward-oriented effort that creates an affordance for the person to live in not-yet-known conditions (Marsico, 2018, p. 12). A human being can pre-adapt to not-yet-known conditions which are made possible by the use of language to create both the person and the culture.

In semiotic theory, it is the openness to possibilities that are implicit in the sociological understanding of reflexivity. Reflexivity is the capacity of an agent to recognize forces of socialization and internalization alternating within their place in the social structure; this is the essence reflexivity as both cause and effect influence one another. Neither the cause nor the effect can be assigned in such a relationship. However, Valsiner's understanding of cultural psychology goes beyond methods and theory and moves into the realm of morality. The personal will becomes an inevitable link between persons in the social world; this relationship becomes a moral one as a lifestyle is seen as a choice within cultural constraints.

By creating and using signs of various forms iconicity and abstraction, human beings regulate their relationship not just merely with the world as-it-is, but also sets the stage for the world as it could (or should) be. In this sense, the notion of society is a moralistic- in contrast a purely ontological-term (Marsico, 2018, p. 341).

A person, which Valsiner sometimes calls a sociogenetic operator of cultural agency, can break free from the constraints and demands of the immediate social environment and thus make him or her dependent upon the personally created meaning that has created that freedom (Marsico, 2018 p. 19). The creation of the concept of a sociogenetic cultural agent highlights the two-way conversation between persons and culture. This moral relationship between the person and the culture is mutually created and therefore responsible and shared.
While others, such as Charles Taylor, have shown that responsibility and respect for others is a culturally developed quality of modernity, Valsiner's statement regarding the ontological quality of morality, is, I think, consistent with Taylor's moral landscapes.

In Valsiner's view, personality is guided by the social and cultural environment. At the same time, personality guides itself through its own construction with the use of semiotically mediated devices. Semiotic systems organize all human personality that originates in social relationships. Semiotic systems "set the stage for their persons direct, suggested, and always canalized movement toward the future - yet at that moment the person is actively constructing his or her own personal life (personal culture)" (Valsiner, 1998.p 385).

To summarize, humans are semiotic agents, that is, we have free will which is rooted in sign creation in use. As persons, we create and are created within and by culture, which we create. Humans, because we are sign creators and users, are future-oriented beings who possess free will. Persons living in this age have created and aided in the creation of the culture of modernity. The relationship between culture and Social Sciences is at the core of developing an under-standing of morality. Sociology provides a somewhat different look. For one such look, we now turned to Anthony Giddens.

\subsection{Anthony Giddens - theory of modernity}

Anthony Giddens outlines some of the grandeur and misery of modernity ${ }^{6}$ from a sociological perspective in Central problems in social theory: action, structure, and contradictions in social analysis (1979), The consequences of modernity (1990), in Modernity and self-identity: self and society in late modern age (1991). He implicitly connects to Valsiner's sociogenetic approach to personality (1998) and Taylor's making of modern identity (1998).

\footnotetext{
${ }^{6}$ See Taylor's The Ethics of authenticity page $120-121$ and this artilce
} 
Giddens provides a short and evolving definition of high or late modernity. In high modernity, the influence of distant happenings influences our proximal experiences and plans, and intimacy becomes commonplace, both in private and public settings. Following that definition of high modernity, the author writes a few paragraphs later that within this new ordering of the world "self-identity becomes a reflexive organized endeavour" (p.5). Giddens writes about the project of the self; meaning that the "self" is an effort of self-creation but conducted with, and within, the current social structures. It is for that reason that it is important to understand the times we live in as that milieu provides the stuff which molds who we are, whether we work in tandem with that environment or against its grain, and that we also shape that environment. The project of self is the creation of a coherent center that is none-the-less under constant revision within a multiple set of choices. Because of the complexity of our world, we must live with the concrete and the abstract simultaneously ( $p$. $5)$.

Reflexivity is a part of both Giddens's and Valsiner's views. Giddens argues that science, technology, and experience are sequestered by a relatively small subset of the population who had the education, wealth, the where-with-all to affectively use these assets, that is, these assets are walled off ${ }^{7}$ and made, more or less, the exclusive property of some people. "The sequestration's experience means that, for many people, direct contact with events and situations which link the individual lifespan too broad issues of morality and finitude are rare and fleeting" (Giddens, 1991, p. 8)

Giddens goes on to define the self as a lived experience, with both nakedly disturbing and sometimes subtle security, intersecting to create a sense of unease. These feelings and foreboding, depression, and restlessness are counterbalanced with experiences of faith in some form of social and technological support. (1990, p. 181). Giddens and

alsiner agree that there exist both social and personal worlds that are related by way of internalization/ externalization mechanisms. Internalization and externalization are unique entities and not comparable.

Anthony Giddens (1991) argues that we, the persons living today, are torn "be-tween two 'extremes' of extensionality and intentionality, that is, globalization influences on the one and personal disposition on the other" (p. 1). The external pressure comes from globalization, and an internal pressure comes from the need for self-creation of a persona. These two pressures are the skeleton of the elements that constitute the ways we grow and develop in late modernity. The external pressure is characterized by the awareness that even distant happenings occur at the moment and affect our awareness at the moment.

Giddens writes about extreme reflexivity of identity stating that the future is reflectively understood based on the present sense of what we are now, but that what we know now when applied to the future will be understood in "appropriately paradoxical ways" (1991, p.29). While referring to the self rather than identity, Giddens sees lifestyle and life planning as a fundamental component of selfconstruction. Life planning is a matter of preparing a course of future action normalized in terms of a self's biography

In the post-traditional order of modernity, and against the backdrop of new forms of mediated experience, self-identity becomes a reflexively organized endeavour. The reflective project of the self, which consists in the sustaining of coherent, yet continuously revised, biographical narratives, takes place in the context of multiple-choice as filtered through abstract systems. In modern social life, the notion of the lifestyle takes on a

\footnotetext{
${ }^{7}$ Compare Taylor's ideas on Buffeting (2007) as presented in this article above.
} 
particular significance. The more traditionloses its hold, the more daily life is reconstituted in terms of the dialectical interplay of the local and the global, more individuals are forced to negotiate lifestyle choices among a diversity of options (p. 5).

In his chapter "The trajectory of the self," Giddens argues that there are a set of existential questions that people living in later modernity are faced with, including: "What to do?' "How to act?" "Who to be?". These questions may be asked and answered, either discursively or by action, that is by living. Autobiographical thinking is a key component in answering these questions. "Reconstructing the past goes along with anticipating the likely life trajectory of the future" (p. 72). By holding a dialogue with the past, we can come to terms with their implication as we identify stressful events (both past events and anticipated events) as well as our tentative answers. It is through the process of this reflection that we create meaning.

In a similar context, Carol Gilligan makes an observation abouther experience working with Erick Erikson when she writes

I remember his phrase, "the meaning of meaning it" (Erikson, 1958). Erik exemplified for me the possibility of being in psychology and meaning it--the possibility of speaking in a first-person voice. He showed that you cannot take a life out of history, that life history can only be understood in history, and that statement stayed with me for a long time. In many ways, it was the inspiration for my work, and when subsequently I connected my life history with history, I discovered that as a woman this connection had very different implications, both psychologically and politically (Gilligan, 1998).

Connecting one's life history to history is to contextualize one's personal development. The process of biographical reflection opens up the possibility of 'Taking charge of one's life'. This process of choosing is to confront a diversity of possibilities open to us. "The individual must be prepared to make a more or less complete break with the past, if necessary, and to contemplate novel courses of action that cannot be simply guided by established habits" (Giddens, 1991, 73).

The development of internal referential systems is at the origin of the reflexive project (1991). There is a fundamental sense in which reflection is a defining characteristic of all human actions $(1990,36)$. In an earlier work, he argues that the reflexive project of the self is based on the duality of structure, that is, the structure is both medium and outcome $(1979,5)$. It is normally within a discourse that the reflective act is consciously articulated. Within the understanding of structured, human agency has to be socially treated as integral to the conceptual grasp of the constitution of social life (1979, p. 255). On the other hand, the reflective monitoring of action draws on tested knowledge and therefore can be only partially and imperfectly expressed in discourse (1979. 40). In other words, as human agents, we must be knowledgeable about how our society works, but that does not mean that we can ex-plain articulately what we have understood tacitly.

The capacity of adapting freely chosen lifestyles is a vital benefit and a demarking characteristic of the self in the modern world. Thus the posttraditional order must deal with the moral dilemmas generated by the choice rich environment of a plurality of values.

How can we remoralize social life without falling prey to prejudice? The more we return to existential issues, the more we find moral disagreement; how can these be reconciled? If there is no transhistorical ethical principle, how can humanity cope with the clashes of true believers without violence? Responsibility is such a problem will surely require a major reconstruction of emancipatory politics as well as the pursuit of life political endeavors (1991, 231).

We can see that all the perspective set before us have a self-reflexive arc, moored in a moral Https://escipub.com/international-journal-of-social-research/ 13 
component based on a sense of agency within the milieu of modernity This self-reflexivity is sometimes explicitly expressed and sometimes implicitly processed. To further explore and extend the understanding of these phenomena, we now turn to Hermans's dialogical self.

3.4 Hubert Hermans-The theory of identity in democracy

Hermans draws on the work of Giambattista Vico, Hans Vaihinger, George Kelly, Jerome Bruner, and, most importantly, Mikhail Bakhtin for his inspiration that led to the concepttualization of this concept. Both the dialogical self and the connections between the dialogical self, and democratic society is spelled out in the opening of Society in the self: A theory of identity in democracy (2018).

Rather than considering society is an external cause or context, this book deals with society is working in an internal domain of the self. In a similar vein, democracy is not only treated as an organizing principle of a modern society but also, and even primarily, as having its fertile source in a deeper layer of the self and identity (Hermans, 2018, 1).

Raggatt (2007) writes that the dialogical self contains two great metaphors that make a good heuristic: (1) the self is in conversation between different "I" positions, and (2) the dialogical self may be conceptualized as a society of mind (356-7). This heuristic is also stated by Hermans and Hermans-Konopka (2010) when they observe that social interactions such as dialogue and fighting are marked in society at large. But to understand how this dialogue takes place it is a considerable value to understand the centrality of " $\mathrm{l}$ " positions in Hermans's dialogical self-theory.

Rom Harré's positioning theory (Harré \& van Langerhove, 1999) is explored briefly here, not because it is central to the formulation of the theory of the dialogical self, but because positioning theory provides a helpful way of understanding the dialogical self and its implications connecting the Social Sciences to modernity. To position the self is to orient the self within social, cultural, political, and some-times physical space. The positioning triangle picture here it represents how positions, speech acts, and storing lines interact. Positions are understood within a cluster of rights and duties. These acts may include probability or deniability of access. Speech in the understanding of Harré should be interpreted as an act and a socially meaningful significant performance. A storyline is similar to a plot, that is, it is a more or less chronological unfolding of a lived experience.

With this brief understanding of positioning theory, we will go on to look at the role of positioning in the theory of identity in democracy, that is, the dialogical personality as societies of the self. Positioning always takes place within and is created by the storyline on the part of the participants. In every conversation, parties assume or take a position concerning the other party. This is also true when the conversation takes place within a person. The idea that the self is polyphonic, that is, it is constituted by different voiced positions. A part of the theory's origin story is contained in the work of Mikhail Bakhtin's discussion of Fyodor Dostoevsky, Polyphonic Novels. "In Bakhtin's dialogical view, that "l" is defined not as a stable or continuous point of consciousness but as a product of dialogical relationship in the field or landscape of "l" positions (Raggatt, 2007, 356). The dialogical self is a dynamic multiplicity of I-positions in the landscape of the mind. Each voice within the dialogical self has a continuity in time in the form of "a story to tell about his or her own experience from his or her own stance" (Hermans, 2002, 148).

The storyline emphasizes the importance of the dynamics of social episodes, and how they unfold. A storyline is a pattern of behavior.

If we take the view that life unfolds as a narrative, with multiple, contemporaneous interlinking storylines, the significance of the action that people carry out, including speech acts, is partly determined by the then-and-there position of the actors. To 
have a footing in a social episode, one must at least have some recognized rights (Harré et al., 2009, 8).

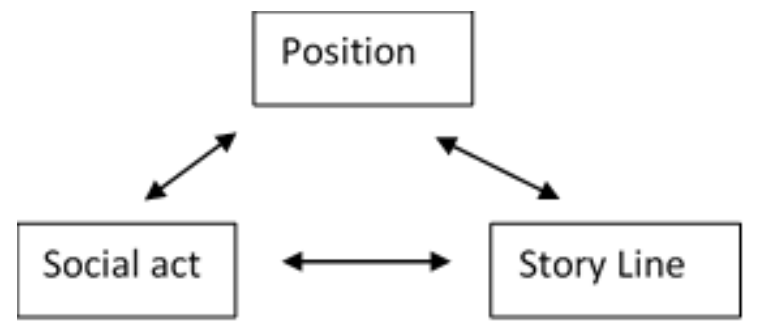

Jerome Bruner, in Acts of meaning (1990), provides an extended understanding of Harré's line of reasoning by stating criteria for narrative. First, narrative emphasizes action or agency. Secondly, narrative is sequentially ordered, that is, it must be stabilized and maintained; storied events need to be linearly realized in standard ways. Thirdly, narratives also require a sensitivity to what is canonical and what violates the canonical in any experience. Finally, narrative requires approximating an author's perspective: it requires a voice (Bruner, 1990, 77).

I-positioning takes place within a narrative. Multiple I-positions take place within a self. Democracy is a form of government characterized by multiple voices seeking unity within a diversity of voices in the body politic. With this back-ground on narrative and positioning theory, Hermans examination of the "dialogical self" connects to our discussion of modernity by integrating the democratic nature of the person, the self, with democratic societies. "In analogy to the tension between freedom and equality in Democratic society, the question is posed how the self, in its organizing capacity, respond to the apparent tension between freedom and equality of the components of the self' (Hermans, 2018, 1).

Autonomy is an essential part of a democratic society as is a jointly undertaken effort. This paradoxical pairing is also found within the dialog within the society of the self. "... this society of mine functions ideally in a democratic society in which positions have the space to express themselves from their own specific point of view and add value to each other in mutually fertilizing ways" $(2018,299)$. Hermans explores how these tensions within a self and within society by illustrating that internal dialogue is not simply a succession of thoughts. This internal dialog is more than alternative voices addressing each other. Hermans sees instead a process organized based on opposite I-positions that engage with each other. The emphasis in the dialogical self is the dialogical nature of thinking. Dialogical thought occurs in relation to internal dialogue a discussion be-tween and among I-positions (p. 305).

In a chapter entitled "Dialogical democracy in a boundary-crossing world", Hermans addresses one of the elements of importance to our examination of modernity: strategies to cope with uncertainty. He presents five coping strategies for reducing uncertainty: 1) decreasing the number of diverse I-positions in the repertoire, (2) giving the lead to one more dominate position thus allowing that position to control the self- system as a whole, (3) creating more clearly defined and shaped boundaries between and among I-positions, (4) counterintuitively increasing, instead of diminishing, the number of positions of the self, and (5) going into, rather than away from, uncertainty rather than avoiding it also has the potential to reduce uncertainty $(2018,375-377)$. While these strategies are not the same as those discussed by Valsiner, Taylor, or Giddens, nor are they the same as strategies for coping and understanding modernity to be discussed in the next section on Resonance (2019), I think the reader will find a certain commonality in the way all these theorists confront the issues raised in their presentation of modernity.

\subsection{Hartmut Rosa - A sociology of our relationship to the world}

Rosa begins Resonance: a sociology of our relationship to the world (2019) by stating the premise of the work, "If acceleration is the problem, then resonance may well be the solution" (1). Perhaps not surprisingly, the exploration of resonance begins in one of Rosa's earlier books, Social acceleration: a new theory of modernity (2013). In that work, Rosa, 
following Anthony Giddens and others, argues that from the actor perspective, the mediation of time may occur on three levels: 1) the natural time structure of everyday life, 2) the development of a perspective on life as a whole, and 3) the experience of everyday time "in their lifetime as embedded in the encompassing time of their epoch, their generation, and their age" $(2013,8)$. The epoch of modernity, however, is a time of acceleration. The radical increase of recording capacity, new media, and the ease of travel have meant that "time is beginning to lose its unilinear orientation giving character because the connection of sequence in chronology appears to become progressively dissolving" $(2013,102)$.

In addition to the considerations of time and media, the actor perspective is of importance as we begin an unfolding examination of modernity. Rosa is also influenced by what Foucault understands a subject's relationship to the self. Foucault sees the subject as being influenced by institutionally structures that have shaped the course of modernization. Modern "disciplinary society", that is, societies that have been transformed by institutionalizing the structure of time in service of social ends, are deficit in or lacking resonance (Rosa, 2013).

An understanding of resonance, however, awaits a discussion of Foucault's planning power utilizing internalized time structures as a key element of a disciplinary society. Adherence to strict time discipline plays in outstanding role in our ability to suppress resonance. The patterns of activities are constantly determined according to rigid abstract time schemes. The rhythm and pace of our lives are less under our control than we might think. These temporal structures have a collective nature and a social character beyond the control of individuals. The time structure of modernity "stands above all under the sign of acceleration" (Rosa, 2013, $x x v i i i)$. These time schemes are the central goal of disciplinary work. The clock represents the surveillance instrument par excellence. The clock was the key machine of the industrial age. A time discipline that consists of an ability to accommodate one's action according to an abstract time schema. The metaphor of the clock as an abstract time machine has made time a fixed schema that encouraged delay gratification, the suspension of impulses, and condition peak performance based on an abstracted version of time as lived. The power of the clock has only increased in our time $(2013,167)$.

This leads us to a look at Rosa's outline (2016) of four structural elements of modernity that need to be understood before looking at his solutions. These elements are 1) open-ended ethical horizons, 2) ethical privatization, 3) the mode of dynamic stabilization, and 4) the mode of competition. An open-ended ethical horizon is defined within the context of two questions: a) what should we do? and b) how should we live? The next structural element, ethical privatization, can be stated as follows - it's up to each of us to demand the answer to the two questions raised in the open-ended ethical world of today. The du-al and paradoxical concepts of an authentically created self and the reinvention of the self are internally examined in terms of our relationship to the world. The answers to the questions of how we are to live are the basis for self-reflexive understanding of these fundamental changes, which are formed within an accelerated temporal structure. And the question of how we want to live is equiva-lent to the question of how we want to spend our time (Rosa, 2013, xxviii).

A successful life is shaped by the idea that subjects are beings possessed by a complex, individual, in generally unfathomable inner depth $(2019,21)$, that is, their authentic self. Implicit in one's ability to reflect on the good life is that we as functioning agents have at least a tacit understanding of the way society work (Giddens, 1991). This tacit understanding of the social structure coupled with an inner sense of self "supplies them with standards and criteria that determine for distinguishing between right and wrong life decisions" (Rosa, 2019, 21).

A discussion of resonance can now begin with an overview of Rosa's approach, his three axes 
of resonance provide a helpful framework. These approaches are: (1) the horizontal axis that includes familial, personal, romantic, and political relationships, (2) the diagonal axes which include work, school, sports and art, and (3) the vertical axes which include the promise of religion, the voice of reason, the power of art and the mantle of history. A successful life may be characterized by a good working order along these axes, and unsuccessful life by the absence or muting of these axes.

Embedded within an understanding of resonance are the concepts of authenticity, selfefficacy, and alienation. A discussion of alienation begins, perhaps with Karl Marx's Economic and philosophical manuscripts of 1844, and proceeds toward a complex thinking and rethinking of this key concept through Weber, and Durkheim and the critical theorist. Rosa's continuing effort to define resonance leads him to an examination and critique of a non-alienated person that may be tentatively defined in the following quote from Marx.

Assume man to be man and his relationship to the world to be a human one: then you can exchange love only for love, trust for trust, etc. If you want to enjoy art, you must be an artistically cultivated person; if you want to exercise influence over other people, you must be a person with a stimulating and encouraging effect on other people. Everyone of your relations to man and to nature must be a specific expression, corresponding to the object of you are will, of your real individual life. If you love without evoking love in turn- that is if you you're loving is it is loving does not produce reciprocal love; If through a living expression of yourself as a loving person you do not make yourself a loved person, then your love is impotent - a misfortune. (Marx, E\&P manscrips1844, 105).

Rosa builds some issues found in Marx's thoughts on labor. Labor is among the ways we relate to the world. Rosa, following Marx, sees labor as a means for attaining self-efficacy and therefore of establishing a resonant relationship with the world.

According to Rosa, Marx sees work as actively grappling with nature as the key to understanding human relationship to the world in general. Marx, unlike almost no other, has a sense for the dimension of self-efficacy in resonant relationships, and it is from this perspective that he defines the pathology of modern human relations to labor and the world (Rosa, 2019, 321).

The connection between resonance and selfefficacy is an active, interpersonal, tactile, and sensual one. Rosa goes on to say that these connection between resonance and self-efficacy may be called labor. "Forms of relating to the world through work form the constitutive basis for human sociality and thus for social conditions in relationships" (34-5).

The third and fourth structural elements, the mode of dynamic stabilization and competition are less discussed by Valsiner, Taylor, Giddens, and Hermans and instead follow a more Foucauldian and critical theory-based approach. Rosa also draws from and builds on the works of Weber, Marx, Horkheimer, Fromm, Marcuse, and other in the social criticism school of thought examines the successful and unsuccessful relationships to the social, physical, and cultural world, that is, the lived experience of engaging or rejecting of the world. The quality of human life requires examining the relationship between the world that shapes their lives These critical theorists have used alienation as a tool for understanding and criticizing modernity. Social alienation increases along with the productive power of society. There is more and more pressure on social arrangements to allow for the lives of individual human beings to share in the wealth of human capacities which belong to social labor. "Alienation is measured by the gap between actual and potential self-realization, the latter being defined in terms of the level of development of the productive forces" (Elster. 1985, 75). However, Rosa argues that alienation is too 
limiting a concept for understanding modernity as it is not just the options that are available or the access to resources that shape this relationship. The prevailing modern notion that the quality of life is necessarily improved by increasing options and resources as put forward by advocates of the values of modernity is also misleading.

On the contrary, there is good reason to assume that the internal dynamic and escalatory logic of modernity places an ever-increasing burden on how human beings relate to the world. The expression of a problematic relationship to the world is historically established existential sensibilities as the cornerstones for a sociology of human relationships to the world. These sensibilities evolve over time as their coloring and refractive light affect persons across class, ethnicity, and cultures (Rosa, 2018). With the increase of recording capacity and new media, "time is beginning to lose its unilinear Orientation- giving character because the connection sequence in chronology appears to become progressively dissolving $(2013,102)^{8}$.

The mode of dynamic stabilization and the mode of competition, on the other hand, move into new territory in the exploration of modernity. The mode of dynamic stabilization is an imperative of modern society. Rosa argues that the core of modernity is based on continuous growth, acceleration, and motivation. Therefore, one structural component of modernity is the mode of competition, which is represented by its central role in the allocation of power which generates the psychological and motivational energy needed to fulfill a culture's imperative, i.e., dynamic stabilization. "In social space, human beings fight to improve their position and their share of the world through the development inflexible and convergence of money and assets, of education, knowledge, skills along with the degrees in credentials that come with them, as well as it developing as well as by developing, maintaining, and leveraging their social networks and even through their physical attractiveness" $(2019,24)$.

As we have seen in Michelle Foucault's foreshadowing above, before a society based in dynamic stability is established, human beings need to be socialized into discipline and planning power employing the establishment in the internalization of time structures. Foucault has shown that institutions that have instituted this planning process (prisons schools, barracks, hospitals, and workhouses) may be characterrized by their ability to provide the strict regulation of time $(2013,7)$. This Foucauldian view of modernity is, in general term, consistent with the major theorist feature in this article, though Herbert Hermans makes little direct reference to Foucault's work.

The role of dynamic stability, on the other hand, has received less consideration by the authors discussed in this paper. Dynamic stabilization, on a personal level, can be characterized as "running in place' or picking up the speed at which we work, play, and plan in order to maintain our status and place in the world. On a social, cultural, and economic level, dynamic stability means that we need to consume more, produce more, and generate more economic growth to achieve what we did in the immediate past. Or to use an old saw, "the faster I go, the 'behinder' I get". Rosa argues that modern societies are capable only of dynamic stabilization. "Structurally, they are geared toward continuous progress by means of growth, acceleration, and innovation, and this not only creates a temporal and spiritual, technological and economic tendency towards escalation that consistently pushes back the horizons of the possible but also ensures that the kinetic or transformative energy of society remains high" ( 2019, 21).

Competition has a broad social logical definition; It is an approach for the allocation of motor and cognitive power sources that are honed within

\footnotetext{
${ }^{8}$ These are the same or very similar issues to those raised by Valsiner, Taylor, Giddens, and Hermans.
} 
the military barracks, schools, industrial enterprises, and prisons of societies. The military and resonance are, in a way, polar opposites, however, they create a tone of life in the barrack and similar social con-texts. The cultural achievement in military education and training, mass education, and industrial training are dominant cultural instruments of contemporary society. Taken together these social/cultural instruments helped to create a disciplinary routine "reification of one's own body and movement along with immunization against one's own well-being as foreign, (e.g., empathetic) impulses, wants and needs" (Rosa, 2018, 398-9).

With Rosa's understanding of the four elements of modernity, that is, open-ended ethical horizons, ethical privatization, the mode of dynamic stabilization, and the mode of competition and some understanding of the value of alienation as a conceptual sociological tool, we can begin a more specific exploration of resonance.

Resonances are the result and expression of a specific kind of relationship between two entities, in particular between the experiencing subject and the segments of the world it encounters. Whether the relationships that develop in a given interactive context are resonant or mute in nature thus depends and both the state and the subject and that of the world it encounters, as well as on their correlation to each other $(2019,381)$.

The socio-structural and cultural conditions of the world, according to Rosa, both predetermine what can be encountered, and also coform the basic form of what is subjectively possible in any given relationship to the world (381). Relationships to the world are not individual accomplishments. but rather are large, and perhaps even to a critical extent culturally and structurally institutionalized. Resonance theory proceeds from the assumption that relational prestige, both in the experiences of acting subject and the form of the objects encountered, are givens. and that it is this encounter, in their meeting with each other, a dancing relationship between them is in each case stabilized and reinforced. Rosa sees resonance as a metacriteria for a successful life (451).

\section{Summary of themes, directions and questions stated explicitly or implicitly by the theorist of modernity}

A summary of the themes bundled together will be put forward in section 4.1.These themes will be woven into an attempt to answer three questions regarding the place and value of articulating an understanding of modernity, the role of narrative and semiotics as shaping the structure of society as well as the role is agency. This mutually interactive construction of society and self is the most prominent theme of all the theorist under consideration here. Their unique ways of stating these constructions creates a dynamic vision that no one of them individually has thus far created.

\section{4,1 General summary of themes all five books}

Several themes stand out in all five books: the integration of self and culture as developmental processes, the search from a moral or ethical bases for values, and the importance of a narrative, semiotic understanding of our relationship to the world. While these are not the only possible themes, they are the ones that seem most salient to our understanding of our time. Charles Taylor provides the most extended chronology of the self as he begins with the ancients. His philosophical perspective includes the major areas of philosophy ethics, aesthetics, ontology, and epistemology. Taylor's reading includes significant psychologist and sociologists.

All of the theories discussed here work to make our tacit understanding of ourselves and our relationship to the world more explicit, thus enabling self-improvement and improvement of the society. Some of the key concepts that they see as needing fuller understanding are the shrinking of space, the acceleration of time, constancy of motion, and self-conscious 
reflexivity. All the theorist work to make that tacit understanding of modernity explicit so as to better operate within the society as it exists, but also to allow for the possibility of changing themselves and their society.

Perhaps one of the themes, which might go unnoticed because it is been sneaking into the social or human sciences for some time now, is the integration of sociology and psychology while drawing on philology and philosophy as their bridge. This process may be seen as coming full circle, that is, sociology and psychology made great efforts during the nineteenth and early twentieth centuries to separate themselves from philosophy are now finding ways integrate their methods and approaches by returning to their roots.

While it takes many forms, I think that Taylors most reoccurring theme is understanding the moral landscape of each age while advocating for strong evaluations, and the articulation of a moral roadmap, that is, what Taylor calls a moral topography. A moral/ethical life is also a key theme in the writings of Hartmut Rosa and Anthony Giddens. Both of these sociologists draw on several of the founders of their discipline who have outline a theory of alienation as being rooted in a capitalist/consumer society. By drawing on Marx, Durkheim, and Weber as well as the Frankfort School scholars, Giddens and Rosa both integrate their moral, ethical orientation within the context of a developmentally understood agency and modernity. Giddens ethics is based on an understanding the mediated experience in which self-identity becomes a reflexively organized endeavour $(1991,5)$. Rosa understand resonance as an approach to repairing our relationship to the world.

Valsiner and Hermans also view modernity in the context of their discipline, that is, psychology. These two theorists look more at the meaning of agency, or the type of agent operating, within a modern social structure.

Valsiner argues that personality emerges through social relations and their cultural organization. Over time, a personality, though socially formed becomes relatively autonomous from the society that partially created it. "Thus, personality is simultaneously socially dependent and individually independent, with both parts of the whole being mutually interdependent" (Valsiner, 1998, 1). This socially dependent and individual independence is explained in Valsiner's chapter on "semiotic regulation of psychological processes.

Human existence is organized by socially constructed and personally internalize semeiotic means- signs of different kinds. Signs become presentations of some aspect of the experienced phenomena as they are being constructed by a person from the needs of communication - with others and with oneself. Thus, signs are vehicles for cultural mediation of any psychological function that entails reflection upon any aspect of the ontological flow of experience $(1998,234)$.

Hermans's understanding of the social nature of the self may be seen as an elaboration of Valsiner's sociogenetic self. Society is not an external cause or context of the self but rather society's working in the internal domains of the self. "And in similar vein, democracy is not only treated as an organizational principle of modern society but also, even primarily, as having a fertile source in the deeper layer of self and identity" $(2018,1)$. Both authors see human and social development working in unison in a semiotic environment. It is the use of signs that changes the person and the society. "If we take the view that life unfolds as a narrative, with multiple, contemporaneous interlinking storylines, the significance of the action that people carry out, including speech acts, is partly determined by the then-and- there position of the actors. To have a footing in a social episode, one must at least have some recognized rights" (Harré et al., 2009, p. 8).

4.2 What is the value of looking at historical periods, specifically, modernity? 
Charles Taylor sets the bar for providing a sweeping history of modernity and the evolution of our understanding of the self. Taylor not only introduces many readers to threads in the history of philosophy but also illustrates the importance of some connections which are continuous and other that reoccur. Importantly, Taylor recovers forgotten threads that often remain silent in many accounts. The weaving of these threads is presented to the reader in the form of narrative.

Thus, narrative as progressive stories in history or especially within the history of the Enlightenment and the Romantic periods and extended into the Victorian era and our times is used by Taylor to highlight the ways in which the self is regularly re-created within history and culture. Many of these stories go beyond childhood and adolescence which have no ending point. They include construals of life's growth, not just childhood and adolescence, and extend to the life cycle. Unlike Erik Erikson, stages of development, these stories do not play out in predetermined stages but rather "they tell a story of growth towards often unprecedented ends" $(1998,105)$. Taylor points to Proust as providing an example of a person as the creator of his own life. Proust has stuck a deep chord in our imagination, Taylor argues. Additionally, he further sees the Christian narrative of divine history as a spiral picture of history. This story of history is also been incorporated and secularized by Marxists and a host of other theories. Taken together these narratives have had an immensely powerful in its hold on modern thought and feelings (105-106). In short, the history of ideas provides a guide to understanding modernity.

Anthony Giddens and Hartmut Rosa also present a historical picture of the development of the self. Their close attention to the effort of sociology as the discipline addressed social issues becomes a tool for understanding our current times. These sociologists, while not ignoring the wider history of the self, primarily draw from sociology.
The dominant sources of the dynamic of modernity according to Giddens (1990), are the separation of time and space, the development of dissembling mechanisms, and the reflexive appropriation of knowledge. One issue that Giddens explores is reflexivity (cf. 1990; 1991). Reflexivity is an interaction between individuals and society. Neither the individual nor the society can be defined without the other, but only in relationship with the other. "The production of systematic knowledge about social life becomes integral to system reproduction, rolling social life away from the fixities of tradition" $(1990,53)$. Time, space, motions and consciousness are tools for understanding our social structure. Time and space constriction and expansion has necessitated the abstraction needed for understanding the world and our embeddedness in a reflexively interactive social structure.

Although time may be more elaborately addressed by Rosa in both Social Acceleration (2013) and Resonance (2016). However, the key orientation of Resonance is its historical examination of alienation beginning with Marx through Weber and Durkheim to Adorno, Marcuse, Horkheimer, and Fromm to Habermas and them to Foucault. The move from alienation to resonance is Rosa's contribution to the history of ideas and how that history aid n-in our understanding of modernity.

Valsiner and Hermans places great emphasis on the development of the individual as socially constructed. Valsiner's historical understanding of the self is presented mainly in two works: The guided mind: a sociogenetic approach to personality (1998) and The social mind: Construction of the idea (Valsiner \& van der Veer, 2000). In The social mind, they provide an overview of "the intellectual interdependencies between thinkers on the theme of 'persons as social beings' in the history of social sciences between 1880s and 1930s" (385). This can be seen in his articulation of the value of Mead, Vygotsky, Peirce, Saussure, and Bühler among others. All researcher who follow the sociogenetic approach profess a belief that "all 
sociological functions are social first, and become personal by a process of developmental 'in-growth"' (Valsiner \& van der Veer, 2000, 391). In the icon-index-symbol trichotomy, Charles Pierce differentiated and emphasized the dynamic nature of signs. He claims that symbols disolvine of the grow. Citing Buchler $(1955,115)$ Valsiner writes, "They come into being by development out of other signs, particularly from icons, from mixes signs partaking of the nature of icons and symbols. We think only in signs" $(1998,242)$. Due to this subjective constructivity of persons, signs are extended. The unity of persons and their environment is possible because their interaction produces diversity - at the level of action, simultaneously and intercanectedly, in the signs that are constructed (1998, 281).

The discussion of narrative and signs above lead us to Herbert Herman's dialogical self. In a similar vein Valsiner, Hermans argues that "psychologists who work from this Cartesian perspective operate under the assumption that the self is locked within a separate and enclosed (self-contained) mind, upon which culture operates as merely a source of external stimuli" (Cresswell and Baerveldt, 2011, 264). The two researchers instead build on their understanding of the self and society by turning to, among others, Mikhail Bakhtin and Jerome Bruner. One point that Hermans makes about modernity and the self is that in order to understand the workings of the self in the contemporary global society, there is a difference between the 'other in the self' and the 'society in itself'. He further argues that the self is involved in the construction of a society in the self $(2018,18)$.

Taylor, Giddens, Rosa, Valsiner, and Hermans, together present an argument for why we should work to understand Modernity: Modernity and the self are jointly created, so to understand one we need to understand the other. Importantly to change one, we must also change the other. While the connection between self and society may have been there for millennia, our need to understand this connection has grown in the last several centuries.

4.3. How does the contextualization of a relational world influence modernity's melody and tone?

The dominant sources of the dynamic of modernity, according to Giddens (1990), are the separation of time and space, the development of dissembling mechanisms, and the reflexive appropriation of knowledge. Giddens helps us gain a view of our world from on high. This view provides a powerful tool for self-reflection. Taylor, on the other hand, presents the most comprehensive picture the expression of modernity and the self as represented in what we might call "high culture," that is, philosophy, literature, music and the arts more generally. Taylor's exposition of our shared "high culture" brings our understanding of our world and ourselves to a personal level, as we see ourselves more clearly in stories and the arts than we to in arguments presented as propositions (Bruner, 1986). Rosa brings before us a dilemma that we have been struggling with for centuries, but perhaps best articulated in the mid-nineteenth century by Marx and the sociologist who followed and critiqued his view. The dilemma of alienation becomes a move toward solution with his idea of resonance (Rosa, 2016; 2019).

Hermans and Valsiner afford an understanding of the cultural dynamics of the self. With their emphasis on the developmental aspects of personhood coupled with the developmental nature of the social structure, the reader is able to gain a near simultaneous perspective on the self/world dynamics. Self-creation within a culture is a hallmark form Valsiner and Hermans. They developing system acquired relative autonomy- relative to immediate environmental demands- to preemptively prepare themselves for the future. Valsiner states that human personality is a self-organizing system that constantly reconstructs itself. "The social environment is to be viewed is making it possible for the personality system to rearrange itself in 
many unique forms, not necessarily along the signs of the social expectations of any particular setting" (1998, 386-387). Hermans in a similar ways states: "... this society of mind functions ideally in a Democratic society in which positions have the space to express themselves from their own specific point of view in and value to each other in a mutually fertilizing way $(2018,299)$.

The melodies of modernity are counter punctually and improvised, played in a full conductorless orchestra. The tone is alternately brash and soothing within a cacophony of democratic horns, woodwinds, strings, and drums. This conception of the melody and tone of modernity is not fully underdeveloped here, but perhaps this hint of an overarching melody enriched by counter melodies and occasionally discordant noises provides a sense of our experience of modernity.

4.4 What roles do narrative and semiotics play in human and cultural development and modernity?

Human development and cultural development are intrinsically intertwined. The acceleration and the irreversibility of time plays an important part in societal and personal development. While stories and narrative have always played an important part in cultural development, the role of narrative in individual human development has been somewhat undervalued. This is especially true in the value of self-reflection within the context of people consciously telling their own stories. For much of history humans have understood their lives in the stories of other people in the form of biography, theatre productions, and histories. Plutarch's Lives is one early example of seeing one's individual life in the life of a hero. As Arendt points out, a Hero is defined by a character in a story told by others. Socrates is known by Plato's stories about him, for example. Arendt claimed that the meaning of action itself is dependent upon the articulation retrospectively given to it by historians and narrators. These are the stories of social and cultural history.
The stories we tell ourselves is a relatively new phenomenon, beginning no doubt before Freud, but Freud help make our self-stories of value to us both as constructor and hearer of our own stories. Bruner in Actual Minds, Possible Worlds (1986) write about the two landscapes of a story. There is a landscape of action and a land scape of consciousness. The landscape of action involves an agent, intention or goals, a situation and some instruments of action. The landscape of consciousness involves what those involved in the action know, or feel, or do not know, or feel. "The two landscapes are distinct: it is the difference between Oedipus sharing Jocasta's bed before and after he learns from the messenger that she is his mother" (14).

My argument is that both our cultural history and our personal history require interpretation with the tools of the two landscapes, that is, the landscape of action and the landscape of consciousness that Bruner outlines (1986). Our social or cultural history is often interpreted within the broad strokes of philology, the history of ideas, and social theory, while our personal history may be interpreted in more finely grained pixels with internal dialogue (cf. Bruner, 1986; 1990; Hermans, 2018, Marsico, 2018; McAdams, 1993).

"Narrative deals with the vicissitudes of intention" (Bruner, 1986, 17), including personal intentions. That is to say, the variations in the stories I tell myself need to be interpreted, this is a part of what Giddens writes about as selfreflexivity. Intention is immediately and intuitively recognizable, while also requiring interpretation. The stories of others, as well as the stories we tell ourselves, are united by the underlying themes that contain three interwoven constituents: a plight into which the characters have fallen because of intentions gone awry, or because of the qualities of the character, or some combination of the two. "It requires an uneven distribution of underlying consciousness among the characters with respect to the plight". ... The story is united is when the plight, character, consciousness interacts to yield a 
structure that has a beginning and a sense of ending" (21). When the storyteller is the subject of the story, McAdams sees this process as developing personal myths, that is, stories we live by (1993).

Bruner argues that the human condition is better understood as a way that humans construct the world than it is to establish the ontological status of that world $(1986,46)$. Bruner argues that it is helpful for us to abandon the idea that the world is there for the beginning

"and substitute for it in idea that what we take as the world is itself no more nor less than a stipulation couched in a symbolic system" (105). If we discharge that assumption the shape of the of our reality alters radically. "And we are at last, in a position to deal with the myriad forms that reality can take - including the realities created by story as well as those created by science" (105).

The symbolic worlds that we live in are both social/cultural and person/interpersonal. These worlds are stories within stories. The five writers we featured here (Taylor, Giddens, Rose, Valsiner, and Hermans - with a little help from Marx, Horkheimer, Weber, Mead, Foucault, and Bruner among other) each contribute in their own ways to our understanding of the role of narrative and semiotics as tools for understanding modernity.

\section{References}

[1]. Bohmann, U, Keding, G., \& Rosa, H. (2018) Mapping Charles Taylor, Philosophy and Social Criticism 44 (7) 725-733.

[2]. Bruner, J.S., 1962. On Knowing: essays on the left hand. Harvard University Press.

[3]. Bruner, J.S., 2009. Actual minds, possible worlds. Harvard university press.

[4]. Bruner, J.S., 2009. Actual minds, possible worlds. Harvard university press.

[5]. Christopher, J.C., 2007. Culture, moral topographies, and interactive personhood. Journal of Theoretical and Philosophical Psychology, 27(2-1), p.170.

[6]. Cresswell, J. and Baerveldt, C., 2011. Bakhtin's realism and embodiment: Towards a revision of the dialogical self. Culture \& Psychology, 17(2), pp.263-277.
[7]. Erikson, E.H., 1959. Identity and the life cycle: Selected papers.

[8]. Giddens, A., 1979. Central problems in social theory: Action, structure, and contradiction in social analysis (Vol. 241). Univ of California Press.

[9]. Giddens, A., 1991. Modernity and self-identity: Self and society in the late modern age. Stanford university press.

[10]. Giddens, A., 2013. The consequences of modernity. John Wiley \& Sons.

[11]. Gilligan, C., 1998. Remembering Larry. Journal of Moral Education, 27(2), pp.125-140.

[12]. Hermans, H.J., 1996. Voicing the self: From information processing to dialogical interchange. Psychological bulletin, 119(1), p.31.

[13]. Hermans, H. and Hermans-Konopka, A., 2010. Dialogical self theory: Positioning and counter-positioning in a globalizing society. Cambridge University Press.

[14]. Hermans, H. and Hermans-Konopka, A., 2010. Dialogical self theory: Positioning and counter-positioning in a globalizing society. Cambridge University Press.

[15]. Harré, R., Moghaddam, F., Pilkerton Cairnie, T., Rothbart, D. and Sabat, S. (2009) Recent advances in positioning theory. Theory and Psychology, 19(1): 5-31. doi: $10.1177 / 0959354308101417$.

[16]. Harré, R. and Van Langenhove, L. (1999) Positioning Theory: Moral contexts of intentional action. Oxford: Blackwell.

[17]. Mattingly, C., Lutkehaus, N.C. and Throop, C.J., 2008. Bruner's search for meaning: A conversation between psychology and anthropology. Ethos, 36(1), pp.1-28.

[18]. Moya, C., 1990. The philosophy of action: An introduction.

[19]. Marsico, G., 2018. Beyond the mind: Cultural dynamics of the psyche. IAP.

[20]. Marx, K., 1844. Economic and philosophical manuscripts. Early writings, 333.

[21]. Polanyi, M. (1958a) Personal Knowledge: toward a post-critical philosophy. Chicago, University of Chicago press.

[22]. Polanyi, M (1958b). The study of man. Chicago, University of Chicago press.

[23]. Raggatt, P.T., 2007. Forms of positioning in the dialogical self: A system of classification and the strange case of Dame Edna Everage. Theory \& Psychology, 17(3), pp.355-382.

[24]. Rosa, H., 2013. Social acceleration: A new theory of modernity. Columbia University Press.

[25]. Rosa, H., 2019. Resonance: a sociology of our relationship to the world. John Wiley \& Sons. 
[26]. Rosenberg, S.W., 2008. The not so common sense: Differences in how people judge social and political life. Yale University Press.

[27]. Taylor, C., 1985. Human agency and language. Cambridge: Cambridge University Press.

[28]. Taylor, C. (1988). The moral topography of the self. In S. B. Messer, L. A. Sass, \& R. L. Woolfolk (Eds.), Rutgers symposia on applied psychology, Vol. 2. Hermeneutics and psychological theory: Interpretive perspectives on personality, psychotherapy, and psychopathology (p. 298320). Rutgers University Press.

[29]. Taylor, C., 1989. Sources of the self: The making of the modern identity. Harvard University Press.

[30]. Taylor, C., 1992. The ethics of authenticity. Harvard University Press.

[31]. West, C., 1999. The Cornel West reader.

[32]. Vaihinger, H., 2009. The Philosophy of 'As If': A System of the Theoretical, Practical and Religious

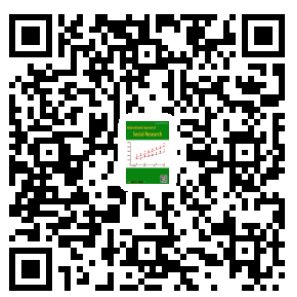
Fictions of Mankind (Eastford).

[33]. Valsiner, J., 1998. The guided mind: $A$ sociogenetic approach to personality. Harvard University Press.

[34]. Valsiner, J., and Van der Veer, R, 2000. The social mind: Construction of the idea. Cambridge University Press.

[35]. Valsiner, J. (2001), Process structure of semiotic mediation in human development, In Human development, 44,2/3,84-97

[36]. Valsiner, J. (2001), Process structure of semiotic mediation in human development, In Human development, 44,2/3,84-97 